\title{
Genetic variability and selection for laticiferous system characters in Hevea brasiliensis
}

\author{
Paulo de Souza Gonçalves ${ }^{1}$, Átila Bento Beleti Cardinal ${ }^{2}$, Reginaldo Brito da Costa ${ }^{3}$, \\ Nelson Bortoletto ${ }^{4}$ and Lígia Regina Lima Gouvêa ${ }^{5}$ \\ ${ }^{1}$ APTA, Instituto Agronômico, Programa Seringueira, Campinas, SP, Brazil. \\ ${ }^{2}$ APTA, Instituto Agronômico, Pós-graduação, Bolsista FAPESP, Campinas, SP, Brazil. \\ ${ }^{3} U C D B$, Programa Desenvolvimento Local, Campo Grande, MS, Brazil. \\ ${ }^{4}$ APTA, Regional do Noroeste Paulista, Votuporanga, SP, Brazil. \\ ${ }^{5}$ APTA, Instituto Agronômico, Bolsista CNPq, Campinas, SP, Brazil.
}

\begin{abstract}
Six laticiferous system characters were investigated in 22 three-year-old, half-sib rubber tree [Hevea brasiliensis (Willd. ex Adr. de Juss.) Muell.-Arg.] progenies, evaluated at three sites (Votuporanga, Pindorama and Jaú, all in the São Paulo State, Brazil). The traits examined were: average rubber yield (Pp), average bark thickness (Bt), number of latex vessel rings (Lv), average distance between consecutive latex vessel rings (Dc), density of latex vessels per $5 \mathrm{~mm}$ per ring averaged over all rings (Dd) and the diameter of the latex vessels (Di). The joint analysis showed that site effect and progeny $x$ sites interaction were significant for all traits, except Lv. Estimates of individual heritabilities across the three sites were high for Bt; moderate for Lv, Pp and Dc; low for Dd and very low for Di. Genetic correlations in the joint analysis showed high positive correlations between $\mathrm{Pp}$ and the other traits. Selecting the best five progenies would result in genetic gains of $24.91 \%$ for Pp while selecting best two plants within a progeny would result in a $\mathrm{Pp}$ genetic gain of $30.98 \%$.
\end{abstract}

Key words: Hevea brasiliensis, rubber yield, laticiferous traits, genetic parameters.

Received: August 7, 2004; Accepted: April 12, 2005.

\section{Introduction}

The rubber tree [Hevea brasiliensis (Willd. ex Adr. de Juss.) Muell.-Arg.] is a perennial crop which has a long generative and testing cycle for individual trees in that it normally takes about four to five years for one generative cycle (excluding a seven to ten years of evaluation period for perennial performance) and about 20 to 30 years for one testing cycle from the time of cross-pollination (Tan, 1987).

The economic product of the tree is latex (a cytoplasmic fluid from the laticiferous cells), which can be continually extracted from the tree by repeatedly slicing off a thin layer of trunk bark in a process called "tapping". Latex is typically contained in tubes and cells collectively known as laticifers, branched or unbranched tubular structures which in many species form a very complex laticiferous system by anastomosis between tube. (Gomez, 1982).

In principle, studying the biometrical genetics of the laticiferous system should shed light on the pattern of in-

Send correspondence to Paulo de Souza Gonçalves. Instituto Agronômico de Campinas, Programa Seringueira, Caixa Postal 28 , 13001-970 Campinas, SP, Brazil. E-mail: paulog@iac.sp.gov.br. heritance in rubber trees, one potentially useful aspect of such a study being that it could assist breeders in the choice of parents when planning breeding programs. Several workers (Tan, 1981; Gonçalves et al., 1999, Costa et al., 2002) have concluded that yield variation can be largely accounted for by additive genetic variance.

The purpose of our present study was to provide further estimates of heritabilities and genetic gains for the laticiferous system (bark thickness, number of latex vessel rings, distance between consecutive latex vessel rings, density of latex vessels per $5 \mathrm{~mm}$ averaged over all rings) and rubber yield in trees at three different sites and also to determine genetic and phenotypic associations between these traits.

\section{Material and Methods}

\section{Plant material and site locations}

Our sample consisted of 22 three-year-old progenies obtained from open-pollinated seeds of clones phenotypically selected from a $H$. brasiliensis population of Asian origin. The following parental clones were selected: 
AVROS 49, AVROS 255, AVROS 352, AVROS 363, AVROS 1328, AVROS 1126, C 228, C 259, C 297, C 318, GT 127, GT 711, PB 49, PB 86, PB 5/63, PR 107, RRIM 513, RRIM 600, Tjir 1 and Tjir 16.

The progeny tests were set up at three different regional poles on the plateau region of the Brazilian state of São Paulo, these poles belonging to the São Paulo state Agribusiness Technology Agency (APTA).

The Center-west Regional Pole, is at Jaú $\left(22^{\circ} 17^{\prime} \mathrm{S}\right.$, $48^{\circ} 34^{\prime}$ W; altitude $580 \mathrm{~m}$ ) where the soil is a Koandiudox and the topography is flat and well-drained. An Aw (Köppen) climate predominantes in this region which has a well-defined dry season, an annual mean temperature of $21.6^{\circ}$, a mean annual rainfall of about $1.344 \mathrm{~mm}$ and an average humidity of about $70 \%$ with extremes of $77 \%$ in February (summer) and 59\% in August (winter).

The Center-north Regional Pole is at Pindorama $\left(21^{\circ} 13^{\prime} \mathrm{S}\right.$; $4^{\circ} 856^{\prime} \mathrm{W}$; altitude $\left.560 \mathrm{~m}\right)$ where the soil is Paleudox. The climate is tropical, with a wet summer and a dry winter period. Mean monthly temperatures vary from 16.6 to $28.9^{\circ} \mathrm{C}$, and annual mean rainfall is $1,390 \mathrm{~mm}$. The period from October to April usually has favorable precipitation for growth and production. Rainfall deficit and low temperatures occur from May to September.

The Northwest Regional Pole at Votuporanga $\left(20^{\circ} 25^{\prime} \mathrm{S} ; 49^{\circ} 50^{\prime} \mathrm{W}\right.$; altitude $450 \mathrm{~m}$ ) has a Paleudalf soil and tropical climate with a hot wet summer and a dry winter with low temperatures and rainfall. Mean monthly temperature varies from 20 to $25^{\circ} \mathrm{C}$ and annual mean rainfall from 1,087 to $1,537 \mathrm{~mm}$. The winter drought varies from four to six dry months, with an average water deficiency of 180 $\mathrm{mm}$.

The rubber tree seeds were collected at the Experimental Center of the Campinas Agronomic Institute (Instituto Agronômico Campinas (IAC), Campinas, São Paulo, Brazil), germinated in polyethylene bags at the three experimental stations and taken to their definitive planting locations when the seedlings had two leaf whorls. In the field the seedlings (henceforth called progenies) were planted according to a randomized complete block design with 22 progenies, five replications and 10 plants per plot spaced at $1.5 \times 1.5 \mathrm{~m}$ in single rows. The progenies were assessed when they were three years old.

\section{Measurements}

Determination of rubber yield $(\mathrm{Pp})$ was made using the principle of the Hamaker-Morris-Mann test (HMM) (Tan and Subramanian, 1976). For latex vessel determination, virgin bark sample plugs were removed from the trunk at a position $20 \mathrm{~cm}$ from the ground on the opposite side to that of the tappings panel. The traits examined were: Average bark thickness $(\mathrm{Bt})$; number of latex vessel rings (Lv); average distance between consecutive latex vessel rings (Dc); density of latex vessels per $5 \mathrm{~mm}$ per ring averaged over all rings (Dd); and the diameter of the latex vessel
(Di), detailed procedures for these measurements having been described by Gonçalves et al. (1995).

\section{Data analyses}

Individual analyses of variance were carried out on the data for each plant. For the joint analysis of all the data sets we used a mathematical model which considered sites and progenies as random effects and was equivalent to the following equation described by Cruz and Regazzi (1994):

$$
Y_{i j k}=\mu+r_{k}+p_{i}+a_{j}+p a_{i j}+e_{i j k}
$$

where $Y_{i j k}$ is the observed value of the $i$ th progeny of the $j$ th site in the $k$ th replication; $\mu$ the general mean; $r_{k}$ the effect of the $k$ th replication; $p_{i}$ the effect of the $i$ th open-pollinated progeny; $a_{j}$ the effect of the $j$ th site, $p a_{i j}$ the effect of the $i$ th progeny $i$ th and $j$ th site and $e_{i j k}$ the effect of the $k$ th ortet within the $i$ th progeny in the $j$ th site replication.

The open-pollinated offsprings were assumed to be half-sibs. Components of variance due to replication within sites $\left(\hat{\mathrm{s}}_{b}^{2}\right)$, phenotypic variance due to differences among plants within progenies $\left(\hat{\mathbf{s}}_{w}^{2}\right)$, environmental variance among progenies $\left(\hat{\mathrm{s}}_{e}^{2}\right)$, genotypic variance among progeny means $\left(\hat{\mathrm{s}}_{g}^{2}\right)$, genotypic variance due to differences among plants within progenies $\left(\hat{\mathrm{s}}_{g w}^{2}\right)$ were calculated from the expectations of mean squares (Vencovsky and Barriga, 1992). All these analyses were performed using the 'Genes' computer program, Windows version (Cruz, 2001). The total phenotypic variance $\left(\hat{\mathrm{s}}_{p t}^{2}\right)$ was obtained using the expression:

$$
\hat{\mathrm{s}}_{p t}^{2}=\hat{\mathrm{s}}_{w}^{2}+\hat{\mathrm{s}}_{e}^{2}+\hat{\mathrm{s}}_{g}^{2}+\hat{\mathrm{s}}_{b}^{2}
$$

\section{Heritabilities}

Heritabilities of individual plants $\mathrm{h}\left(h_{i}^{2}\right)$, within progeny $\left(h_{w}^{2}\right)$, and among progeny means $\left(h_{\bar{x}}^{2}\right)$ levels for each progeny test were estimated as:

$$
\begin{aligned}
h_{i}^{2} & =\frac{4 \hat{\mathrm{s}}_{g}^{2}}{\hat{\mathrm{s}}_{g}^{2}+\hat{\mathrm{s}}_{e}^{2}+\hat{\mathrm{s}}_{w}^{2}} \\
h_{w}^{2} & =\frac{\hat{\mathrm{s}}_{g w}^{2}}{\hat{\mathrm{s}}_{w}^{2}} \\
h_{\bar{x}}^{2} & =\frac{\hat{\mathrm{s}}_{g}^{2}}{M S P / \bar{n} r},
\end{aligned}
$$

where $\bar{n}$ is the harmonic mean of the number of plants within plots, $r$ the number of replications and MSP the mean square of the progenies.

The joint analysis heritability estimates for individual plants $\left(h_{i}^{2}\right)$ and half-sib progenies mean $\left(h_{\vec{x}}^{2}\right)$ were used according to Vencovsky and Barriga (1992), as follows:

$$
h_{i}^{2}=\frac{3 \hat{\mathbf{s}}_{g}^{2}}{\hat{\mathrm{s}}_{g}^{2}+\hat{\mathrm{s}}_{g e}^{2}+\hat{\mathrm{s}}_{e}^{2}+\hat{\mathbf{s}}_{w}^{2}}
$$




$$
h_{\bar{x}}^{2}=\frac{\hat{\mathrm{s}}_{g}^{2}}{\hat{\mathrm{s}}_{g}^{2}+\left(\hat{\mathrm{s}}_{g e}^{2} / a\right)+\left(\hat{\mathrm{s}}_{e}^{2} / a r\right)+\left(\hat{\mathrm{s}}_{w}^{2} / a r \bar{n}\right)},
$$

where, $\hat{\mathrm{s}}_{g e}^{2}$ is the variance due to genotypic-environment interaction, $a$ the number of sites, $r$ the number of replications and $\bar{n}$ the harmonic mean of the number of plants within a plot.

The coefficients of genotypic variation $\left(C V_{g} \%\right)$ for individual and joint analyses were estimated using the formula described by Vencovsky (1983):

$$
C V_{g} \%=100 \sqrt{\frac{\hat{\mathrm{s}}_{g}^{2}}{\bar{x}}}
$$

Similarly, the phenotypic and experimental variation coefficients were estimated, where $\bar{x}$ represents the general mean of the trait.

Genetic gain from selection among progeny $\left(G_{g}\right)$ and within progeny $\left(G_{w}\right)$ levels was computed using Falconer and Mackay (1996) formulas:

$$
\begin{aligned}
G_{g} & =\frac{k_{1} \hat{\mathrm{s}}_{A}^{2}}{4 \sqrt{\hat{\mathrm{s}}_{g}^{2}+\left(\hat{\mathrm{s}}_{e}^{2} / r\right)+\left(\hat{\mathrm{s}}_{w}^{2} / n r\right)}} \\
G_{w} & =\frac{3 k_{2} \hat{\mathrm{s}}_{A}^{2}}{4 \sqrt{\hat{\mathrm{s}}_{w}^{2}}}
\end{aligned}
$$

where $k_{1}$ is the among progeny selection intensity (45\%) and $k_{2}$ the within progeny selection intensity $(10 \%)$.

The genetic gains expressed as a percent of the among and within progeny means were estimated using the formula:

$$
\begin{aligned}
& G_{g} \%=\frac{G_{g}}{\bar{x}} \cdot 100 \\
& G_{w} \%=\frac{G_{w}}{\bar{x}} \cdot 100,
\end{aligned}
$$

where $\bar{x}$ is the general mean.

To examine the relationship among the yield traits of Hevea plants at different sites, genetic $\left(r_{g(x y)}\right)$ and phenotypic $\left(r_{p(x y)}\right)$ correlation coefficients were calculated according to Kempthorne (1966), as follows:

$$
\begin{aligned}
& r_{g(x y)}=\frac{\operatorname{Cov}_{g(x y)}}{\sqrt{\hat{\mathrm{s}}_{g x}^{2} \cdot \hat{\mathrm{s}}_{g y}^{2}}} \\
& r_{p(x y)}=\frac{\operatorname{Cov}_{p(x y)}}{\sqrt{\hat{\mathrm{s}}_{p x}^{2} \cdot \hat{\mathrm{s}}_{p y}^{2}}}
\end{aligned}
$$

where $\operatorname{Cov}_{g(x y)}$ and $\operatorname{Cov}_{p(x y)}$ are the genotypic and phenotypic covariances for traits $x$ and $y$ respectively; $\hat{\mathrm{s}}_{g x}^{2}$ and $\hat{\mathrm{s}}_{p x}^{2}$ are the genotypic and phenotypic variances for trait $x ; \hat{\mathrm{s}}_{g y}^{2}$ and $\hat{\mathrm{s}}_{p y}^{2}$ are the genotypic and phenotypic variances for trait $y$. Correlation analyses were performed using ver- sion 1.0 of the 'Selegen' computer program (Resende and Oliveira, 1997).

The significance of these correlations was tested using the simple correlation table in Fisher and Yates (1971) for simple correlation for $5 \%$ and $1 \%$ probabilities. The genotypic and phenotypic correlation coefficients were tested using the degrees of freedom of the error.

\section{Results and Discussion}

\section{Individual analysis of variance for all locations}

With the exception of the number of latex vessel rings (Lv) in the Votuporanga population and the density of latex vessels per ring (Dd) and latex vessel diameter (Di) in both the Votuporanga and Pindorama populations, the six traits studied showed significant differences $(\mathrm{p}<0.05$ and $\mathrm{p}<0.01$ ) in the individual analyses of variance (Table 1). This suggests that differences were attributable to genetic causes and that selection within each Hevea population included in this study is possible. Average rubber yield (Pp) was $0.85 \mathrm{~g}$ per individual plant (ortet) the lowest $\mathrm{Pp}$ value was $0.61 \mathrm{~g}$ per ortet and occurred in the Votuporanga population while the highest Pp value was $0.99 \mathrm{~g}$ per ortet in the Pindorama population, $62 \%$ higher than in the Votuporanga population. At the three locations bark thickness $(\mathrm{Bt})$ averaged $3.80 \mathrm{~mm}$ per ortet, the lowest average $\mathrm{Bt}$ value being $3.76 \mathrm{~mm}$ per ortet in the Jaú population and the highest $3.85 \mathrm{~mm}$ per ortet in the Votuporanga population, $3 \%$ higher than in the Jaú population.

The number of latex vessels (Lv) averaged 3.29 units per ortet, the lowest average Lv value being 3.05 units per ortet in the Votuporanga population and the highest 3.15 units per ortet in the Jaú population, 3\% higher than in the Votuporanga population. Although the experimental sites were at similar latitudes, longitude and altitude in the São Paulo plateau region the performance of the progenies varied, suggesting the involvement of other environmental factors such as soil type, fertility and structure.

\section{Joint analysis of variance}

The joint analysis of variance showed highly significant $(\mathrm{p}>0.01)$ differences among progenies for $\mathrm{Pp}, \mathrm{Bt}, \mathrm{Lv}$ and Dc (Table 2). These variations indicate good prospects for both selection program and general continuity in the Hevea genetic breeding program. The experimental coefficients of variation $(\mathrm{CV} \%)$ showed were high for $\mathrm{Pp}$ $\left(C V_{e}=32.65 \%\right)$, moderately high for $\operatorname{Lv}\left(C V_{e}=12.18 \%\right)$ and Dc $\left(C V_{e}=12.12 \%\right)$ and moderately low for $\mathrm{Bt}$ $\left(C V_{e}=9.04 \%\right)$ and $\mathrm{Di}\left(C V_{e}=9.43 \%\right)$. These values express the intrinsic properties of the traits. These values agreed with similar estimates by Gonçalves et al. (1998), Moreti et al. (1994), Boock et al. (1995) and Costa et al. (2000a). Except for Lv, the effect of site was significant on all traits, indicating that they were affected by site variation under the conditions of the present study. The progeny-location inter- 
Table 1 - Mean squares, coefficient of experimental variation $\left(C V_{e} \%\right)$ and coefficient of genetic variation $\left(C V_{g} \%\right)$ for six different traits of the bark laticiferous system in 22 three-years-old open pollinated Hevea progenies growing at three sites in the Brazilian State São Paulo.

\begin{tabular}{|c|c|c|c|c|c|c|c|c|}
\hline \multirow[t]{2}{*}{ Sites } & \multirow[t]{2}{*}{ Traits $^{1}$} & \multicolumn{4}{|c|}{ Analysis of variance mean square values ${ }^{2}$} & \multirow[t]{2}{*}{ Mean } & \multirow[t]{2}{*}{$C V_{e} \%$} & \multirow[t]{2}{*}{$C V_{g} \%$} \\
\hline & & Replications (R) & Progenies $(\mathrm{P})$ & $\mathrm{P} \times \mathrm{R}$ & Within plot & & & \\
\hline \multirow[t]{6}{*}{ Votuporanga } & $\mathrm{Pp}$ & 0.4452 & $0.8770 * *$ & 0.2853 & 0.2688 & 0.61 & 7.67 & 20.62 \\
\hline & $\mathrm{Bt}$ & 1.5492 & $5.9193 * *$ & 0.8562 & 0.6588 & 3.85 & 8.27 & 8.99 \\
\hline & Lv & 0.8551 & $1.6018 \mathrm{n} . \mathrm{s}$. & 1.1226 & 0.5879 & 3.05 & 12.12 & 3.54 \\
\hline & Dc & 0.0095 & $0.0449 * *$ & 0.0108 & 0.0085 & 0.32 & 11.37 & 9.02 \\
\hline & $\mathrm{Dd}$ & 31.2553 & 73.3875n.s. & 77.1367 & 40.8389 & 46.30 & 6.63 & - \\
\hline & Di & 105.3573 & 17.5892n.s. & 20.1426 & 14.2827 & 19.00 & 9.21 & - \\
\hline \multirow[t]{6}{*}{ Pindorama } & $\mathrm{Pp}$ & 0.5372 & $7.0787 * *$ & 1.0143 & 0.5807 & 0.99 & 34.91 & 34.84 \\
\hline & $\mathrm{Bt}$ & 1.5766 & $11.9116^{* *}$ & 0.9609 & 0.6098 & 3.80 & 8.80 & 12.12 \\
\hline & $\mathrm{Lv}$ & 1.2880 & $4.3488^{* *}$ & 1.0368 & 0.6771 & 3.06 & 11.44 & 10.34 \\
\hline & $\mathrm{Dc}$ & 0.0102 & $0.0378 * *$ & 0.0138 & 0.0082 & 0.32 & 12.67 & 6.82 \\
\hline & $\mathrm{Dd}$ & 149.8487 & 105.5731n.s. & 104.7621 & 46.4484 & 45.03 & 7.78 & 0.28 \\
\hline & Di & 27.0902 & 34.7806n.s. & 28.5751 & 12.6741 & 17.16 & 10.79 & 2.05 \\
\hline \multirow[t]{6}{*}{ Jaú } & $\mathrm{Pp}$ & 0.7282 & $0.9959 *$ & 0.4954 & 0.2529 & 0.94 & 28.75 & 16.68 \\
\hline & $\mathrm{Bt}$ & 2.2674 & $8.1624 * *$ & 1.3206 & 0.5676 & 3.76 & 10.58 & 9.83 \\
\hline & Lv & 32.7214 & $6.6046^{* *}$ & 1.5609 & 0.6762 & 3.15 & 13.92 & 10.22 \\
\hline & $\mathrm{Dc}$ & 0.0217 & $0.0354 *$ & 0.0104 & 0.0475 & 0.25 & 13.87 & 8.75 \\
\hline & Dd & 267.8469 & $140.5422 * *$ & 49.4823 & 21.4847 & 43.74 & 5.60 & 3.10 \\
\hline & $\mathrm{Di}$ & 133.1510 & $48.3380 * *$ & 25.8348 & 9.9836 & 17.52 & 10.08 & 3.84 \\
\hline
\end{tabular}

$* \mathrm{p}<0.05 ; * * \mathrm{p}<0.01 ;$ n.s. $=$ not significant.

${ }^{1}$ Key (units in parenthesis): $\mathrm{Pp}=$ rubber yield $(\mathrm{g})$; Bt $=$ bark thickness $(\mathrm{mm}) ; \mathrm{Lv}=$ number of latex vessel rings; Dc $=$ average distance $(\mu \mathrm{m})$ between consecutive latex vessel rings (based on all rings); $\mathrm{Dd}=$ density of latex vessels per $5 \mathrm{~mm}$ per ring, averaged over all rings; $\mathrm{Di}=\mathrm{diameter}(\mu \mathrm{m})$ of latex vessels. ${ }^{2}$ Degrees of freedom were: 5 for replication, 21 for progeny and 105 for residual for all traits.

Table 2 - Estimates of variance due to replication within sites $\left(\hat{\mathrm{s}}_{b}^{2}\right)$, genetic variance among progeny means $\left(\hat{\mathrm{s}}_{g}^{2}\right)$, environmental variance among progenies $\left(\hat{\mathrm{S}}_{e}^{2}\right)$, phenotypic variance within progenies $\left(\hat{\mathrm{S}}_{w}^{2}\right)$, genotypic variance due to differences among plants within progenies $\left(\hat{\mathrm{s}}_{g w}^{2}\right)$, heritabilities of individual plants $\left(\hat{h}_{i}^{2}\right)$, among progeny means $\left(\hat{h}_{\bar{x}}^{2}\right)$, and within progeny $\left(\hat{h}_{w}^{2}\right)$ levels for five different laticiferous system in 22 three-years-old open-pollinated Hevea progenies growing at three sites in the Brazilian State of São Paulo.

\begin{tabular}{lccccccc}
\hline \multirow{2}{*}{ Sites } & \multirow{2}{*}{$\begin{array}{c}\text { Variances } \\
\text { components }\end{array}$} & \multicolumn{7}{c}{ Traits $^{1}$} \\
\cline { 3 - 8 } Votuporanga & $\hat{\mathrm{s}}_{b}^{2}$ & 0.0010 & 0.0374 & - & - & - & 0.4687 \\
& $\hat{\mathrm{s}}_{g}^{2}$ & 0.0109 & 0.1201 & 0.0116 & 0.0008 & - & - \\
& $\hat{\mathrm{s}}_{e}^{2}$ & 0.0022 & 0.0234 & 0.0648 & 0.0003 & 4.4387 & 0.7091 \\
& $\hat{\mathrm{s}}_{w}^{2}$ & 0.2688 & 0.6588 & 0.5879 & 0.0084 & 40.8390 & 14.2827 \\
& $\hat{\mathrm{s}}_{g w}^{2}$ & 0.0484 & 0.3602 & 0.3487 & 0.0025 & - & - \\
& $\hat{h}_{i}^{2}$ & 0.2249 & 0.5987 & 0.3700 & 0.3463 & - & - \\
& $\hat{h}_{\bar{x}}^{2}$ & 0.6748 & 0.8554 & 0.2991 & 0.7586 & - & - \\
& $\hat{h}_{w}^{2}$ & 0.1802 & 0.5468 & 0.0593 & 0.2940 & - & - \\
\hline \multirow{2}{*}{ Pindorama } & $\hat{\mathrm{s}}_{b}^{2}$ & - & 0.0032 & 0.0013 & - & 0.2402 & - \\
& $\hat{\mathrm{s}}_{g}^{2}$ & 0.1187 & 0.2125 & 0.0653 & 0.0005 & 0.0158 & 0.1241 \\
& $\hat{\mathrm{s}}_{e}^{2}$ & 0.0509 & 0.0409 & 0.0426 & 0.0007 & 6.8339 & 0.9061 \\
& $\hat{\mathrm{s}}_{w}^{2}$ & 0.5807 & 0.6098 & 0.6771 & 0.0082 & 46.4484 & 12.6941 \\
& $\hat{\mathrm{s}}_{g w}^{2}$ & 0.3562 & 0.6375 & 0.1960 & 0.0014 & 0.0475 & 0.3424 \\
& $\hat{h}_{i}^{2}$ & 0.6328 & 0.9848 & 0.3329 & 0.2007 & 0.0012 & 0.0337 \\
& $\hat{h}_{\bar{x}}^{2}$ & 0.8567 & 0.9143 & 0.7616 & 0.6347 & 0.0077 & 0.1784 \\
& $\hat{h}_{w}^{2}$ & 0.6133 & 1.0456 & 0.2895 & 0.1712 & 0.0010 & 0.0293 \\
\hline
\end{tabular}


Table 2 (cont.)

\begin{tabular}{|c|c|c|c|c|c|c|c|}
\hline \multirow[t]{2}{*}{ Sites } & \multirow{2}{*}{$\begin{array}{l}\text { Variances } \\
\text { components }\end{array}$} & \multicolumn{6}{|c|}{ Traits $^{1}$} \\
\hline & & $\mathrm{Pp}$ & $\mathrm{Bt}$ & $\mathrm{Lv}$ & $\mathrm{Dc}$ & Dd & Di \\
\hline \multirow[t]{8}{*}{ Jaú } & $\hat{\mathrm{s}}_{b}^{2}$ & 0.0016 & 0.0052 & 0.1752 & 0.0001 & 1.2043 & 0.5863 \\
\hline & $\hat{\mathrm{s}}_{g}^{2}$ & 0.0248 & 0.1367 & 0.1040 & 0.0005 & 1.8414 & 0.4531 \\
\hline & $\hat{\mathrm{s}}_{e}^{2}$ & 0.0360 & 0.0902 & 0.1095 & 0.0047 & 3.3970 & 1.9151 \\
\hline & $\hat{\mathrm{s}}_{w}^{2}$ & 0.2529 & 0.5676 & 0.6762 & 0.0007 & 21.4848 & 9.9836 \\
\hline & $\hat{\mathrm{s}}_{g w}^{2}$ & 0.0744 & 0.4100 & 0.3120 & 0.0014 & 5.5242 & 1.3593 \\
\hline & $\hat{h}_{i}^{2}$ & 0.3161 & 0.6881 & 0.4676 & 0.3279 & 0.2756 & 0.1467 \\
\hline & $\hat{h}_{\bar{x}}^{2}$ & 0.5026 & 0.8382 & 0.7637 & 0.7052 & 0.3479 & 0.4655 \\
\hline & $\hat{h}_{w}^{2}$ & 0.2941 & 0.7224 & 0.4615 & 0.3052 & 0.2571 & 0.1362 \\
\hline \multirow[t]{6}{*}{ Joint analysis } & $\hat{\mathrm{s}}_{g}^{2}$ & 0.0261 & 0.0959 & 0.0294 & 0.0003 & 0.1521 & - \\
\hline & $\hat{\mathrm{s}}_{e}^{2}$ & 0.0709 & 0.1173 & 0.1417 & 0.0013 & 8.3602 & 2.8492 \\
\hline & $\hat{\mathrm{s}}_{w}^{2}$ & 0.3675 & 0.6121 & 0.6471 & 0.0058 & 36.2574 & 12.3201 \\
\hline & $\hat{\mathrm{s}}_{g e}^{2}$ & 0.0241 & 0.0618 & 0.0334 & 0.0003 & 0.5609 & 0.2372 \\
\hline & $\hat{h}_{i}^{2}$ & 0.3243 & 0.3243 & 0.3036 & 0.1169 & 0.0100 & - \\
\hline & $\hat{h}_{\bar{x}}^{2}$ & 0.7586 & 0.7586 & 0.5654 & 0.5947 & 0.1513 & - \\
\hline
\end{tabular}

${ }^{1}$ Key (units in parenthesis): $\mathrm{Pp}=$ rubber yield $(\mathrm{g}) ; \mathrm{Bt}=$ bark thickness $(\mathrm{mm}) ; \mathrm{Lv}=$ number of latex vessel rings; $\mathrm{Dc}=$ average distance $(\mu \mathrm{m})$ between consecutive latex vessel rings (based on all rings); $\mathrm{Dd}=$ density of latex vessel per $5 \mathrm{~mm}$ per ring, averaged over all rings; $\mathrm{Di}=$ diameter $(\mu \mathrm{m})$ of latex vessels.

action effect was also significant on all studied traits. According to Vencovsky (1969) the progeny $x$ site interaction reflects the difference in viability among progenies and the correlation among materials for different traits.

\section{Genetic and environmental parameters}

The genotypic variation coefficient, $\left(C V_{g} \%\right)$ expresses the amount of existing genetic variation as a percentage of the general mean (Table 1), and was higher for $\mathrm{Pp}$ and $\mathrm{Bt}$ followed by $\mathrm{Lv}$ in Pindorama $(\mathrm{Pp}=34.84 \%$, $\mathrm{Bt}=12.12 \%$ and $\mathrm{Lv}=10.34 \%)$, Jaú $(\mathrm{Pp}=16.68 \%$, $\mathrm{Bt}=9.83 \%$ and $\mathrm{Lv}=10.22 \%)$ and Votuporanga $(\mathrm{Pp}=20.62 \%, \mathrm{Bt}=8.99 \%$ and $\mathrm{Lv}=3.54 \%)$. These results confirmed the $\mathrm{F}$ test results for progeny differences and characterized these traits as being suitable for expressing the genetic variability of the population studied. These results also agree with those reported by Gonçalves et al. (1998) and Boock et al. (1995) for the same traits.

As a percentage of the total phenotypic variance based on individual plants $\left(\hat{\mathrm{s}}_{p}^{2}\right)$ the genetic variance components among progenies for Pp accounted for $3.85 \%$ in the Votuporanga population, $7.87 \%$ in the Pindorama population and $15.82 \%$ in the Jaú population (Table 2). As a percentage of phenotypic variance, the contribution of genotypic variance among progenies $\left(\hat{\mathrm{s}}_{g}^{2}\right)$ was $17.09 \%$ for $\mathrm{Bt}$ (bark thickness) and $16.45 \%$ for Lv (number of latex vessel rings) in Jaú and was substantially greater than the $\hat{\mathrm{s}}_{g}^{2}$ values for $\mathrm{Bt}(14.30 \%)$ and $\mathrm{Lv}(1.75 \%)$ in Votuporanga. On the other hand, the $\hat{\mathrm{s}}_{g}^{2}$ values for $\mathrm{Bt}(24.17 \%)$ and $\mathrm{Lv}$ $(8.30 \%)$ were substantially greater in Pindorama and smaller in Votuporanga. In addition, except for the joint analysis, genotypic variance components among progeny means were always higher than those for the environmental effects (Table 2).

\section{Heritabilities}

On individual plant level, Pp heritabilities $\left(\hat{h}_{i}^{2}\right)$ moderately high for Votuporanga (0.22), Jaú (0.32) and Pindorama (0.63) while $\mathrm{Bt}\left(\hat{h}_{i}^{2}\right)$ values were all high in that they were 0.60 at Votuporanga, 0.69 at Jaú and 0.98 at Pindorama (Table 3). Our data agreed with that various authors (Costa et al., 2000a, b; Gonçalves et al., 1998, 1999; Boock et al., 1995; Moreti et al., 1994) who reported individual plant heritability values $\left(\hat{h}_{i}^{2}\right)$ of 0.22 to 0.50 for $\mathrm{Pp}$ (rubber yield) and from 0.45 to 0.73 for $\mathrm{Bt}$, indicating that both these traits have moderately high heritability estimates. Our results indicate that there was a large amount of genetic variability in our population. The $\mathrm{Lv} \hat{h}_{i}^{2}$ values were relatively high on an individual basis ( 0.37 for Votuporanga, 0.33 for Pindorama and 0.47 for Jaú) and also for between progeny means $(0.30$ for Votuporanga, 0.76 for Pindorama and 0.76 for Jaú) and within progenies ( 0.06 for Votuporanga, 0.29 for Pindorama and 0.46 for Jaú). The Dd (density of latex vessels) $\hat{h}_{i}^{2}$ values were very low for Pindorama and Jaú on an individual basis ( 0.001 for Pindorama and 0.28 for Jaú) and also between progeny means ( 0.01 for Pindorama and $0.35 \mathrm{Jaú}$ ) and within progenies 0.001 for Pindorama and 0.26 for Jaú), these moderately low heritability estimates indicating that there is a need to 
Table 3 - Heritability coefficients for six different laticiferous system traits of 22 three-year-old open-pollinated Hevea progenies growing at three sites in the Brazilian State of São Paulo.

\begin{tabular}{llcccccc}
\hline \multirow{2}{*}{ Site } & \multicolumn{1}{c}{ Heritabilities } & \multicolumn{3}{c}{ Traits $^{1}$} \\
\cline { 3 - 8 } & & Pp & Bt & Lv & Dc & Dd & Di \\
\hline \multirow{2}{*}{ Votuporanga } & Individual plants $\left(\hat{h}_{i}^{2}\right)$ & 0.2249 & 0.5987 & 0.3700 & 0.3463 & - & - \\
& Progeny mean $\left(\hat{h}_{\bar{x}}^{2}\right)$ & 0.6748 & 0.8554 & 0.2991 & 0.7586 & - & - \\
& Within progeny $\left(\hat{h}_{w}^{2}\right)$ & 0.1802 & 0.5468 & 0.0593 & 0.2940 & - & - \\
\hline \multirow{2}{*}{ Pindorama } & Individual plants $\left(\hat{h}_{i}^{2}\right)$ & 0.6328 & 0.9848 & 0.3329 & 0.2007 & 0.0012 & 0.0337 \\
& Progeny mean $\left(\hat{h}_{\bar{x}}^{2}\right)$ & 0.8567 & 0.9143 & 0.7616 & 0.6347 & 0.0077 & 0.1784 \\
& Within progeny $\left(\hat{h}_{w}^{2}\right)$ & 0.6133 & 1.0456 & 0.2895 & 0.1712 & 0.0010 & 0.0293 \\
\hline \multirow{2}{*}{ Jaú } & Individual plants $\left(\hat{h}_{i}^{2}\right)$ & 0.3161 & 0.6881 & 0.4676 & 0.3279 & 0.2756 & 0.1467 \\
& Progeny mean $\left(\hat{h}_{\bar{x}}^{2}\right)$ & 0.5026 & 0.8382 & 0.7637 & 0.7052 & 0.3479 & 0.4655 \\
\hline \multirow{2}{*}{ Pooled analysis } & Within progeny $\left(\hat{h}_{w}^{2}\right)$ & 0.2941 & 0.7224 & 0.4615 & 0.3052 & 0.2571 & 0.1362 \\
& Individual plants $\left(\hat{h}_{i}^{2}\right)$ & 0.3243 & 0.3243 & 0.3036 & 0.1169 & 0.0100 & - \\
\hline
\end{tabular}

${ }^{1}$ Key (units in parenthesis): $\mathrm{Pp}=$ rubber yield $(\mathrm{g})$; Bt $=$ bark thickness $(\mathrm{mm})$; Lv = number of latex vessel rings; Dc $=$ average distance $(\mu \mathrm{m})$ between consecutive latex vessel rings (based on all rings); Dd = density of latex vessels per $5 \mathrm{~mm}$ per ring, averaged over all rings; $\mathrm{Di}=\mathrm{diameter}(\mu \mathrm{m}) \mathrm{of}$ latex vessels.

increase the genetic variability for latex vessel density in these populations.

It is important to emphasize that these highly significant heritability estimates coupled with the large amount of variation observed within our rubber tree populations suggest that an effort to increase both yield and bark thickness through progeny selection would be rewarding.

\section{Correlations}

High and significant genetic and phenotypic correlations were found for $\operatorname{Pp}\left(r_{g}=0.94, r_{p}=0.85\right.$; both signifi- cant at $\mathrm{p}<0.01)$ and $\operatorname{Lv}\left(r_{g}=0.76, r_{g}=0.77\right.$; both significant at $\mathrm{p}<0.01$ ) between Votuporanga and Jaú (Table 4).

There were high and significant Bt (bark thickness) and Lv (number of latex vessel rings) genetic $\left(r_{g}\right)$ and phenotypic $\left(r_{p}\right)$ correlations between the Votuporanga and Pindorama populations $\left(r_{g}=0.59\right.$ and $r_{p}=0.89$ for $\mathrm{Bt}$; $r_{g}=0.65, r_{p}=0.64$ for Pp. All significant at $\left.\mathrm{p}<0.01\right)$ but the correlations were low for the other traits (Table 4). The high correlations indicate that a single breeding program could satisfatorily serve both the Votuporanga and the Jaú populations. This assertions is valid for both rubber yield, num-

Table 4 - Genotypic $\left(r_{g}\right)$ and phenotypic $\left(r_{p}\right)$ correlations among Votuporanga (1), Pindorama (2) and Jaú (3) sites for rubber yield (Pp), bark thickness (Bt), number of latex vessel rings (Lv), average distance between consecutive latex vessel rings (Dc), density of latex vessels per ring (Dd), diameter of latex vessels (Di) in 22 three-year-old open-pollinated Hevea progenies growing at three sites in the Brazilian state of São Paulo. Site $1=$ Votuporanga, site 2 = Pindorama, site 3 = Jaú.

\begin{tabular}{|c|c|c|c|c|c|c|c|}
\hline \multicolumn{4}{|c|}{$\mathrm{Pp}$} & \multicolumn{4}{|c|}{$\mathrm{Bt}$} \\
\hline Sites & Correlation types & 2 & 3 & Sites & Correlation types & 2 & 3 \\
\hline \multirow[t]{2}{*}{1} & $r_{g}$ & $0.6598 * *$ & $0.9444 * *$ & 1 & $r_{g}$ & $0.5907 * *$ & $0.2679 \mathrm{~ns}$ \\
\hline & $r_{p}$ & $0.6430 * *$ & $0.8460 * *$ & & $r_{p}$ & $0.8901 * *$ & $0.3920 \mathrm{~ns}$ \\
\hline \multirow[t]{2}{*}{2} & $r_{g}$ & - & $-0.1627 \mathrm{~ns}$ & 2 & $r_{g}$ & - & $0.2320 \mathrm{~ns}$ \\
\hline & $r_{p}$ & - & $0.1091 \mathrm{~ns}$ & & $r_{p}$ & - & $0.5254 *$ \\
\hline \multicolumn{4}{|c|}{$\mathrm{Lv}$} & \multicolumn{4}{|c|}{ Dc } \\
\hline Sites & Correlation types & 2 & 3 & Sites & Correlation types & 2 & 3 \\
\hline \multirow[t]{2}{*}{1} & $r_{g}$ & $0.0605 \mathrm{~ns}$ & $0.7569 * *$ & 1 & $r_{g}$ & $0.3733 \mathrm{~ns}$ & $0.1664 \mathrm{~ns}$ \\
\hline & $r_{p}$ & $-0.0088 \mathrm{~ns}$ & $0.7653 * *$ & & $r_{p}$ & $0.4801 *$ & $0.6014 \mathrm{~ns}$ \\
\hline \multirow[t]{2}{*}{2} & $r_{g}$ & - & $0.0841 \mathrm{~ns}$ & 2 & $r_{g}$ & - & $0.2671 \mathrm{~ns}$ \\
\hline & $r_{p}$ & - & $0.6462 * *$ & & $r_{p}$ & - & $0.5620 * *$ \\
\hline
\end{tabular}


Table 4 (cont.)

\begin{tabular}{|c|c|c|c|c|c|c|c|}
\hline \multicolumn{4}{|c|}{ Dd } & \multicolumn{4}{|c|}{ Di } \\
\hline Sites & Correlation types & 2 & 3 & Sites & Correlation types & 2 & 3 \\
\hline \multirow[t]{2}{*}{1} & $r_{g}$ & $-0.0202 \mathrm{~ns}$ & $0.0164 \mathrm{~ns}$ & 1 & $r_{g}$ & $0.0006 \mathrm{~ns}$ & $0.0098 \mathrm{~ns}$ \\
\hline & $r_{p}$ & 0.0000 & $0.5473 * *$ & & $r_{p}$ & $-0.0880 \mathrm{~ns}$ & $-0.1241 \mathrm{~ns}$ \\
\hline \multirow[t]{2}{*}{2} & $r_{g}$ & - & $-0.1138 \mathrm{~ns}$ & 2 & $r_{g}$ & - & $0.0393 \mathrm{~ns}$ \\
\hline & $r_{p}$ & - & 0.0000 & & $r_{p}$ & - & $-0.0019 \mathrm{~ns}$ \\
\hline
\end{tabular}

${ }^{*} \mathrm{p}<0.05 ; * \mathrm{p}<0.01 ; \mathrm{ns}=$ not significant.

ber of latex vessel rings, which can be checked by the genetic correlation between locations (Vencovsky and Barriga, 1992).

Genetic and phenotypic correlation coefficients obtained for Votuporanga and Pindorama had fairly strong genetic correlations for $\mathrm{Bt}\left(r_{g}=0.59, r_{p}=0.89\right.$; both significant at $\mathrm{p}<0.01)$ and medium for $\mathrm{Pp}\left(r_{g}=0.66, r_{p}=0.64\right.$ both significant at $\mathrm{p}<0.01)$ and $\mathrm{Dc}\left(r_{g}=0.37, r_{p}=0.48 ; r_{p}\right.$ significant at $\mathrm{p}<0.05)$. The highest values however, were smaller than those found for the coefficients between Pindorama and Jaú. As in the previous analysis, these results characterized the interaction for rubber yield, indicating that for these traits only one breeding program at one site will satisfy the needs of the other site involved.

In the joint analysis (Table 5) Pp and Dd had fairly strong positive genetic and phenotypic correlations $\left(r_{g}=0.54, r_{p}=0.56\right.$; both significant at $\left.\mathrm{p}<0.01\right)$ suggesting that selection for one trait should lead to strong positive indirect responses in the other. This positive genetic association certainly needs to be verified by further studies across more sites. These findings for three-years-old progeny trials in São Paulo are the opposite to those reported for a one-year-old progeny study in the Amazon where Gonçalves et al. (1984) found adverse genetic associations between latex vessels density (Dd) and rubber yield (Pp) when selectively breeding $H$. brasiliensis for rubber production.

We observed high negative correlations between $\mathrm{Lv}$ and Dc $\left(r_{g}=-0.72, r_{p}=-0.63\right.$; both significant at $\left.\mathrm{p}<0.01\right)$, these findings agreeing with the results reported for other sutdies involving progenies of the same age (Gonçalves et al. 1984)

Genetic correlation values $\left(r_{g}\right)$ for both $\mathrm{Bt}(0.44)$ and $\mathrm{Lv}(0.43)$ were favorably associated with rubber production (Pp), and support the work of Gonçalves et al. (1999, 2004) who found phenotypic correlations of almost the same magnitude $\left(r_{p}=0.42\right.$ and 0.43$)$.

\section{Expected progress with selection}

The estimated narrow sense heritabilities for rubber yield (Pp), bark thickness (Bt) and total number of vessel rings $(\mathrm{Lv})$ varied between sites, with the $\mathrm{Pp}$ and $\mathrm{Bt}$ values being highest values at Pindorama which suggests that high genetic gains could be achieved for these traits at this site

Table 5 - Genotypic $\left(r_{g}\right)$ and phenotypic correlations $\left(r_{p}\right)$ for bark thickness (Bt), total number of latex vessel rings (Lv), average distance (mm) between consecutive latex vessel rings (Dc), density of latex vessels per $5 \mathrm{~mm}$ per ring (Dd) and diameter of latex vessels (Di) in 22 three-year-old open-pollinated Hevea progenies growing at three sites in the Brazilian state of São Paulo. Values represent means for the three sites.

\begin{tabular}{|c|c|c|c|c|c|c|}
\hline & & & Traits & & & \\
\hline Traits & Correlation type & $\mathrm{Bt}$ & $\mathrm{Lv}$ & Dc & Dd & Di \\
\hline \multirow[t]{2}{*}{$\mathrm{Pp}$} & $r_{g}$ & $0.4382 *$ & $0.4657 *$ & $0.3375 \mathrm{~ns}$ & $0.5425^{* *}$ & $0.8628 * *$ \\
\hline & $r_{p}$ & $0.4289 *$ & $0.4305^{*}$ & $-0.2941 \mathrm{~ns}$ & $0.5584^{* *}$ & $0.7716^{* *}$ \\
\hline \multirow[t]{2}{*}{$\mathrm{Bt}$} & $r_{g}$ & & $0.3090 \mathrm{~ns}$ & $0.1263 \mathrm{~ns}$ & $0.3216 \mathrm{~ns}$ & $0.8263^{* *}$ \\
\hline & $r_{p}$ & & $0.2809 \mathrm{~ns}$ & $0.1170 \mathrm{~ns}$ & $0.2463 \mathrm{~ns}$ & $0.4690 *$ \\
\hline \multirow[t]{2}{*}{$\mathrm{Lv}$} & $r_{g}$ & & & $-0.7229 * *$ & $0.4403 * *$ & $0.5558 * *$ \\
\hline & $r_{p}$ & & & $-0.6298 * *$ & 0.3789 & $0.4500^{*}$ \\
\hline \multirow[t]{2}{*}{ Dc } & $r_{g}$ & & & & $-0.2685 \mathrm{~ns}$ & $-0.0346 n s$ \\
\hline & $r_{p}$ & & & & $-0.1506 n s$ & $0.0036 \mathrm{~ns}$ \\
\hline \multirow[t]{2}{*}{$\mathrm{Dd}$} & $r_{g}$ & & & & & $0.6542 * *$ \\
\hline & $r_{p}$ & & & & & $0.7074 * *$ \\
\hline
\end{tabular}

*and ** significant at $5 \%$ and $1 \%$ probability, respectively ns $=$ not significant. 
(Table 3). The prediction of expected progress by selection between progenies assumed a selection intensity (Table 6) of $45 \%$ for all the traits, but the genetic gain values varied considerably for Pp and among the other laticiferous system traits and were especially high for the Bt trait. These values were within the limits obtained by other authors (Paiva et al., 1994; Vasconcellos, 1985; Moreti et al., 1994) and Book et al. (1995). The results also showed a tendency for greater gains when selection took place in Pindorama and Jaú. However, the expected progress in selection intensity for within progeny selection was only $10 \%$, although here again the gain values varied considerably for $\mathrm{Pp}$ and among the other laticiferous system traits and were especially high for the Bt trait. These values were also within the limits obtained by other authors (Moreti et al., 1994; Boock et al., 1995; Costa et al., 2002). The results showed a tendency for greater genetic gains when the within progeny selection took place in Pindorama and, to a lesser extent, Jaú.
Selection gains as a percentage of the between and within progeny means for the other laticiferous system traits such as latex vessel density (Dd) and latex vessels diameter(Di) were relatively low for all sites and somewhat lower than those reported by Boock et al (1995). These low expected gains probably resulted from low heritability estimates with high phenotypic variation in these traits. Zobel and Talbert (1984), however, pointed out that tree breeders can influence selection gains by controlling the environment by maximize heritability. Genetic gain could also be increased by employing an appropriate method of indirect selection (Falconer and Mackay, 1996).

\section{Breeding strategies}

Our results show that it is possible to develop a program for rubber tree improvement. Zobel and Talbert (1984) state that 'progeny plus within-family selection' method (i.e. selecting the best progenies and the best individuals within progenies) is the predominant form of selection used in most advanced generation tree improvement

Table 6 - Expected genetic gain from selection and percentage of the mean among $\left(G_{g}\right)$ within $\left(G_{w}\right)$ progenies and total $\left(G_{t e s t}\right)$ for six different traits of the laticiferous system in 22 three-year-old open-pollinated Hevea progenies growing at three sites in the Brazilian state of São Paulo.

\begin{tabular}{|c|c|c|c|c|c|c|c|}
\hline \multirow[t]{2}{*}{ Location } & \multirow[t]{2}{*}{ Trait $^{1}$} & \multicolumn{3}{|c|}{ From selection } & \multicolumn{3}{|c|}{ In percent of the mean } \\
\hline & & $G_{g}$ & $G_{w}$ & $G_{\text {test }}$ & $G_{g}$ & $G_{w}$ & $G_{t o t}^{2}$ \\
\hline \multirow[t]{6}{*}{ Votuporanga } & $\mathrm{Pp}$ & 0.1013 & 0.0801 & 0.1814 & 16.43 & 13.00 & 29.43 \\
\hline & $\mathrm{Bt}$ & 0.4070 & 0.5636 & 0.9706 & 10.57 & 14.63 & 25.20 \\
\hline & $\mathrm{Lv}$ & 0.3795 & 0.5778 & 0.9573 & 12.46 & 1.90 & 14.36 \\
\hline & $\mathrm{Dc}$ & 0.0311 & 0.0346 & 0.0657 & 9.73 & 10.81 & 20.54 \\
\hline & Dd & - & - & - & - & - & - \\
\hline & $\mathrm{Di}$ & - & - & - & - & - & - \\
\hline \multirow[t]{6}{*}{ Pindorama } & $\mathrm{Pp}$ & 0.4050 & 0.5936 & 0.9986 & 40.96 & 60.04 & 101.00 \\
\hline & $\mathrm{Bt}$ & 0.5613 & 1.0369 & 1.5982 & 14.76 & 27.26 & 42.02 \\
\hline & $\mathrm{Lv}$ & 0.2832 & 0.3025 & 0.5857 & 9.25 & 9.88 & 19.13 \\
\hline & $\mathrm{Dc}$ & 0.0228 & 0.0197 & 0.0425 & 7.18 & 6.20 & 13.38 \\
\hline & Dd & 0.0140 & 0.0088 & 0.0228 & 0.03 & 0.02 & 0.05 \\
\hline & $\mathrm{Di}$ & 0.1889 & 0.1327 & 0.3216 & 1.10 & 0.77 & 1.87 \\
\hline \multirow[t]{6}{*}{ Jaú } & $\mathrm{Pp}$ & 0.1636 & 0.1878 & 0.3514 & 17.34 & 19.90 & 37.24 \\
\hline & $\mathrm{Bt}$ & 0.4299 & 0.6912 & 1.1211 & 11.43 & 18.38 & 29.81 \\
\hline & $\mathrm{Lv}$ & 0.3579 & 0.4819 & 0.8398 & 11.34 & 15.27 & 26.61 \\
\hline & Dc & 0.0176 & 0.0695 & 0.0871 & 7.03 & 27.71 & 34.74 \\
\hline & Dd & 1.3872 & 1.5136 & 2.9008 & 3.17 & 3.46 & 6.63 \\
\hline & Di & 0.5833 & 0.5464 & 1.1297 & 3.33 & 3.12 & 6.45 \\
\hline \multirow[t]{6}{*}{ Average } & $\mathrm{Pp}$ & 0.2233 & 0.2872 & 0.5105 & 24.91 & 30.98 & 55.89 \\
\hline & $\mathrm{Bt}$ & 0.4661 & 0.7639 & 1.2300 & 12.25 & 20.09 & 32.34 \\
\hline & $\mathrm{Lv}$ & 0.3402 & 0.4541 & 0.7943 & 11.02 & 9.02 & 20.04 \\
\hline & Dc & 0.0238 & 0.0413 & 0.0651 & 7.98 & 14.91 & 22.89 \\
\hline & $\mathrm{Dd}$ & 0.7006 & 0.7612 & 1.4618 & 1.60 & 1.74 & 3.34 \\
\hline & $\mathrm{Di}$ & 0.3861 & 0.3395 & 0.7256 & 2.21 & 1.94 & 4.15 \\
\hline
\end{tabular}

${ }^{1}$ Key (units in parenthesis); $\mathrm{Pp}=$ rubber yield $(\mathrm{g})$; Bt = bark thickness $(\mathrm{mm}) ; \mathrm{Lv}=$ number of latex vessel rings; Dc $=$ average distance $(\mu \mathrm{m})$ between consecutive latex vessel rings (based on all rings); Dd = density of latex vessels per $5 \mathrm{~mm}$ per ring, averaged over all rings; $\mathrm{Di}=\mathrm{diameter}(\mu \mathrm{m})$ of latex vessels. ${ }^{2} G_{t o t}=$ total genetic gain $\left(G_{g}+G_{w}\right)$. 
programs and we feel that this method should be adopted for improving rubber yield $(\mathrm{Pb})$, bark thickness $(\mathrm{Bt})$ and the number of latex vessel rings (Lv) in rubber trees growing in São Paulo. Since there was low significant genetic correlation between $\mathrm{Pb}, \mathrm{Bt}$ and $\mathrm{Lv}$ indirect selection is not applicable so 'tandem selection' should be used in which rubber yield is improved first and Bt and number Lv afterwards when rubber production has reached a satisfactory level, although if the intentions is to improve rubber yield and bark thickness simultaneously an 'independent culling' method would be better.

\section{Acknowledgments}

The authors thank to Dr. Antonio Lúcio M. Martins Director of Pindorama Pole for facilities provided. To Miss Graziela dos Santos Lima of the Hevea breeding program, at the Instituto Agronômico (IAC) for her help during this study. P.S.G., L.R.L.G. and A.B.B.C. are recipients of $\mathrm{CNPq}$ and FAPESP fellowships, respectively. This research and publication was supported by FAPESP.

\section{References}

Boock MV, Gonçalves P de S, Bortoletto N and Martins ALM (1995) Estimativas de parâmetros genéticos e ganhos esperados com a seleção de caracteres juvenis em progênies de seringueira. Pesq Agrop Bras 25:135-156.

Costa RB da, Resende MDV de, Gonçalves P de S and Silva M de A (2002) Individual multivariate REML/BLUP in the presence of genotype $\mathrm{x}$ environment interaction in rubber tree (Hevea) breeding. Crop Breed Appl Biotech 2:131-140.

Costa RB da, Resende MDV, Araújo AJ de, Gonçalves $\mathrm{P}$ de $\mathrm{S}$ and Martins ALM (2000a) Genotype-environment interaction and the number of test sites for the genetic improvement of rubber trees (Hevea) in São Paulo State, Brazil. Genet Mol Biol 23:179-187.

Costa RB, Resende MDV de, Araújo AJ, Gonçalves P de S and Higa AR (2000b) Selection and genetic gain in rubber (Hevea) populations using a mixed mating system. Genet Mol Biol 23:671-679.

Cruz CD (2001) Programa Genes: Versão Windows. Aplicativo Computacional em Genética e Estatística. Editora da UFV, Viçosa, 648 pp and CD-ROM.

Cruz CD and Regazzi AJ (1994) Modelos Biométricos Aplicados ao Melhoramento Genético. Imprensa Universitária, Viçosa, 390 pp.

Falconer DS and Mackay TFC (1996) Introduction to Quantitative Genetics. Longman, New York, 320 pp.

Fisher RA and Yates F (1971) Statistical Methods for Research Workers. Oliver and Boyd, Edinburgh, 245 pp.

Gomez JB (1982) Anatomy of Hevea and Its Influence on Latex Production. Malaysian Rubber Research and Development Board, Kuala Lumpur, 75 pp.

Gonçalves P de S, Furtado EL, Bataglia OC, Ortolani AA, May A and Belletti GO (1999) Genetics of anthracnose panel canker disease resistance and its relationship with yield and growth character in half-sib progenies of rubber tree (Hevea brasiliensis). Genet Mol Biol 22:583-589.
Gonçalves P de S, Gallo PB, Segnini Jr I, Ortolani AA, Brioschi AP, Landell MG and Souza SR de (1998) Components of variance and interaction between genotype and environment for annual girth increment in rubber tree. Pesq Agrop Bras 33:1329-1337.

Gonçalves P de S, Martins ALM, Bortoletto N and Saes LA (2004) Selection gains for juvenile traits in progenies of Hevea in São Paulo State, Brazil. Genet Mol Biol 27:207-214.

Gonçalves P de S, Martins ALM, Bortoletto N and Carvalho AZ (1995) Relationship among yield, girth and some structural character of the laticiferous system in young seedlings of rubber trees (Hevea). Braz J Genet 18:421-428.

Gonçalves P de S, Rossetti, AG, Valois, ACC and Viegas, I de J (1984) Estimativas de correlações genéticas e fenotípicas de alguns caracteres quantitativos em clones jovens de seringueira. Rev Bras Genet 2:95-107.

Kageyama PY, Oliveira RS, Ferraz PA, Furtado EL, Souza AD and Sebbenn AM (2002) Genetic gains in the selection for látex productivily in natural populations of Hevea brasiliensis in Chico Mendes Reserve: A case study of the IAPs (Islands of high productively), Scientia Forestalis 61:79-85.

Kempthorne O (1966) An Introduction to Genetic Statistics. John Wiley \& Sons, New York, 455 pp.

Moreti D, Gonçalves P de S, Gorgulho EP, Martins ALM and Bortoletto N (1994) Estimativas de parâmetros genéticos e ganhos esperados com a seleção de caracteres juvenis em progênies de seringueira. Pesq Agrop Bras 29:1099-1104.

Paiva JR, Kageyama PY, Vencovsky R and Contal PB (1994) Genetics of rubber tree (Hevea brasiliensis [(Willd. ex Adr. de Juss.) Muell. Arg]. 1. Genetic variation in natural populations. Silvae Genetica, 43:306-311.

Resende MDV de and Oliveira EB de (1997) Sistema "Selegen" Seleção genética computadorizada para o melhoramento de espécies perenes. Pesq Agrop Bras 32:931-939.

Tan H and Subramaniam S (1976) A five diallel cross analyses for certain characters of young Hevea seedling. In: Rubber Research Institute of Malaysia (ed) Proceedings of the International Rubber Conference. RRIM, Kuala Lumpur, 13-26.

Tan H (1981) Estimates of genetic parameters and their implications in Hevea breeding. In: Yap TC, Graham KM, Sukami J (eds) Crop Improvement Research, Proc. $4^{\text {th }}$ Int. Congr. SABRAO, Kuala Lumpur, 439-446.

Tan H (1987) Strategies in rubber tree breeding. In: Abbott AJ and Atkin RK (eds) Improving Vegetatively Propagated Crops. Academic Press, London 27-62.

Vasconcellos MEC, Gonçalves P de S, Paiva JR and Valois ACC (1985) Métodos de estimação do coeficiente de repetibilidade no melhoramento da seringueira. Pesq Agrop Bras 20:433-437.

Vencovsky R (1969) Genética quantitativa. In: Kerr WE (ed) Melhoramento e Genética. Edusp, São Paulo, pp 17-37.

Vencovsky R (1983) Herança quantitativa. In: Paterniani EC and Viegas GP (eds) Melhoramento e Produção do Milho. Fundação Cargill, Campinas, pp 137-214.

Vencovsky R and Barriga P (1992) Genética Biométrica no Fitomelhoramento. Sociedade Brasileira de Genética, Ribeirão Preto, $486 \mathrm{pp}$.

Zobel B and Talbert J (1984) Applied Forest Tree Improvement. John Wiley \& Son, New York, 505 pp.

Associate Editor: Everaldo Gonçalves de Barros 